\title{
NUCLEAR CRITICALITY SAFETY DEPARTMENT \\ QUALIFICATION PROGRAM
}

\author{
K. J. Carroll \\ R. G. Taylor \\ C. A. Worley \\ Nuclear Criticality Safety Department \\ Health, Safety, Environment and Accountability Organization \\ RECEIVED \\ JAI 031997 \\ OSTI
}

September 6, 1996

Prepared by the

Oak Ridge Y-12 Plant

Oak Ridge, Tennessee 37831 managed by

Lockheed Martin Energy Systems, Inc.

for the

U. S. DEPARTMENT OF ENERGY under contract

DE-AC05-84OR21400

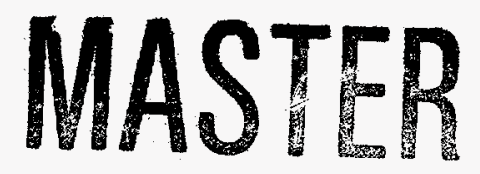


This report was prepared as an account of work sponsored by an agency of the United States Government. Neither the United States Government nor any agency thereof, hor any of their employees, makes any warranty, express or implied, or assumes any legal liability or responsibility for the accuracy, completeness, or usefulness of any information, apparatus, product, or process disclosed, or represents that its use would not infringe privately owned rights. Reference herein to any specific commercial product, process, or service by trade name, trademark, manufacturer or otherwise, does not necessarily constitute or imply its endorsement, recommendation, or favoring by the United States Government or any agency thereof. The views and opinions of authors expressed herein do not necessarily state or reflect those of the United States Government or any agency thereof. 


\section{DISCLAIMER}

Portions of this document may be illegible in electronic image products. Images are produced from the best available original document. 
Y/DD-694, Rev. 3 9/6/96

Page 1 of 18

\title{
LOCKHEED MARTIN ENERGY SYSTEMS, INC.
}

\author{
QUALIFICATION PROGRAM
}

NUCLEAR CRITICALITY SAFETY DEPARTMENT (NCSD)

-ovals:

Qualification Verification Official:

Superintendent, NCSD:




Y/DD-694, Rev. 3

\section{TABLE OF CONTENTS}

oval/Cover Page $\quad 1$

e of Contents 2

Purpose 3

References 3

Scope $\quad 3$

Definitions 3

Qualification Programs $\quad 5$

Task and Duty Assignment Qualifications 7

Program, Task and Duty Assignment Initial Qualification 11

Maintenance of Qualification and Requaiification 16

Qualification Tracking $\quad 17$

Evaluation of Training and Qualification 18

res

Figure 1 - Qualification Paths $\quad 6$

Tables

e 1 - Task and Duty Assignment Qualification 8 
1.1 The Nuclear Criticality Safety Department (NCSD) is committed to developing and maintaining a staff of highly qualified personnel to meet the current and anticipated needs in Nuclear Criticality Safety (NCS) at the Oak Ridge Y-12 Plant. This document defines the Qualification Program to address the NCSD technical and managerial qualification as required by the $Y-12$ Training implementation Matrix (TIM).

1.2 This Qualification Program is in compliance with DOE Order 5480.20A and appticable Lockheed Martin Energy Systems, inc. (LMES) and Y-12 Plant procedures. It is implemented through a combination of LMES plant-wide training courses and professional nuclear criticality safety training provided within the department.

1.3 This document supersedes Y/DD-694, Revision 2, 3/27/96, Qualification Program. Nuclear Criticality Safety Department. There are no backfit requirements associated with revisions to this document.

2.1 DOE Order 5480.20A. Personnel Selection. Qualification. and Training Requirements for DOE Nuclear Faciities

2.2 DOE-STD-1070-94. Guidelines for Evaluation of Nuclear Facility Training Proçroms

2.3 Y90-series Training and Qualification Procedures

2.4 LMES ESS-TQ-series Training and Qualification Procedures

$2.5 \quad$ 10-027, Plant Training Program

2.6 YMD-552. Nuclear Criticality Safety Department Self-Assessment Program

2.7 Y YDD-696. Training implementation. Nuclear Criticality Safety Department

2.8 Y/DD-710, Guidance for the Development of Continuing Technical Training, Nuclear Criticality Safety Department

3.1 This Qualification Program is applicable to all technical and manageriai NCSD personnel, including temporary personnel, sub-contractors and/or LMES employees on loan to the NCSD, who perform the NCS tasks or serve NCS-related positions as defined in sections 5 and 6 of this program.

3.2 NCSD training documents referenced in this program are provided in Y/DD-696.

\section{DEFINITIONS}

4.1 Candidate: an individual who is in the process of selection, training, or qualification.

4.2 Continuing Training: training that is designed to provide assurance that an employee's job assignment proficiency is maintained and ennanced.

4.3 Duty Area: an area of responsibiiity within a job.

4.4 Education: the successful completion of the requrrements established by an accredited 
Y/DD-694, Rev. 3

9/6/96

Page 4 of 18

educational institution.

4.5 Emergency Operations Center (EOC): an accessible area set aside for providing an assembly area for operational support personnel during an emergency situation.

4.6 Entry Level Requirements: the requirements established to ensure that the Candidate possesses the knowledge, skills, and abilities to enter a job.

4.7 Exception: the release of an individual from portions of a training or qualification program through prior education, experience, training, and/or testing.

4.8 Fixed Continuing Training: tasks identified with fixed retraining intervais.

4.9 Flexible Continuing Training: the variable portion of continuing training based on feedback from line management. training evaluations. industry operating events. and changes to the facility and its procedures.

4.10 Individual Development Plan (IDP): a document used to identify and document managerial and administrative responsibilities of a manager or senior staff person. It serves as a guide for the learning activities which address those responsibilities.

4.11 Job Fundamentals Requirements: the basic knowiedge and skills common to all duty areas of a job. These requirements may be deriven from the results of a job analysis, industry standards, or incumbent surveys.

4.12 List of Qualified Personnel: the approved listing of personnel who are qualified to perform NCS Tasks or serve in NCS-related duty assignments.

4.13 Mentor: a one-on-one advisoriguide/coach to personnel in the NCSD professional Qualification Program.

4.14 Mentoring Checklist: an instrument used to identify, guide, and document the professionat development of technical staff at the program level. The checklist contains tearning objectives derived from the applicable tasks/competencies statements.

4.15 Mentoning Checksheet: an instrument used to identify, guide, and document the professional development of technical staff at the task level. The checksheet contains performance standards derived from the applicable tasks/competencies statements for a particular checklist item, and includes evaluations appropriate to the subject matter.

4.16 Nuclear Experience: experience acquired at any facility in which radioactive materials are routinely handled, stored, processed, or utilized.

4.17 Qualification: satisfactory completion of education. experience, training, and any special requirements and/or examinations necessary for performance of assigned responsibilities.

4.18 Qualification Card (Qual Card): a TMS document that lists completed Qualification Program requirements. 
YDD-694, Rev. 3

9/6/96

Page 5 of 18

4.19 Qualification Program: the composne Ist of requirements, based on iob assignment, identified and validated by line management. It includes the formal training process that is used to fully prepare a trainee for the performance of assigned responsibilities.

4.20 Qualification Verification Official (QVO): an individual designated by line management who controls the record copy of the Qualification Program and verifies that candidates meet qualification requirements.

4.21 Requirements/Qualification Status Report: a Training Management System (TMS) report which lists an individuat's assigned training requirements and the status of each requirement. This report is used to track an individual's progress through a training cycle.

4.22 Supervsor: as used in this document, the person to whom a Candidate reports administratively (Group Leader, Department Superintendent. HSEA Manager). The terms “Group Leader" and "Supervisor", as used in this document. are synonymous.

4.23 Task: a defined unit of work.

4.24 Training implementation Matrix (TIM): a matrix which defines and describes the application of the selection, qualification, and training requirements of DOE Order 5480.20A.

4.25 Training Management System (TMS): a data base which reflects the employees hard copy training records. TMS is used to aid the training organization in managing training activities and to assist line management in making work assignments.

5.1 Qualification Programs establish the overall requirements for managerial and technicat positions within the NCSD which are NCS related. NCSD Superintendent, NCS Erigineer in Training, NCS Engineer. NCS Specialist. Technical Specialist. and Continuing Training Programs are provided for NCSD personnel. All NCSD technical and management personnel who perform or approve activities related to NCS shall be enrolled in one or more of the programs. Technical personnel move through the Qualification Programs starting with Engineer in Training, continuing with one of the technical paths, and ending up in the continuing education and training program as illustrated in Figure 1. NCSD Superintendent and NCS Engineer are Training implementation Matrix (TIM) positions. Appropriate education and experience requirements are contained in the programs.

5.2 The NCS Engineer in Training Qualification Program inctudes requirements for education, job fundamentats, basic theory and practice knowiedge, and basic documents knowledge.

5.3 The NCS Engineer Qualification Program includes requirements for continuing training in job fundamentals. as required, duty area access, functional area specific basic facility knowledge, task qualification in tasks $1-4$ described in section 6 , and experience.

5.4 The NCS Specialist Qualification Program includes requirements for continuing training in job fundamentals and duty area access, as required. task qualification in tasks 5 and 6 and 2 additional tasks from tasks $7-9$ described in section 6 , and experience. 
YDD-694, Rev. 3

9/6/96

Page 6 of 18

5.5 The Technical Speciaiist Qualification Program includes requiremenis for continuing trainina in job fundamentals, as required, duty area access, basic facility knowiedge as necessary to support selected specialization tasks, task qualification in 3 tasks from tasks 1 - 9 described in section 6 , and experience.

5.6 The NCSD Superintendent Qualification Program includes requirements for LMES managerial job fundamentals and duty area access supptemented with an Individual Development Plan (IDP).

5.7 The Continuing Training Qualification Program inciudes fixed and flexible requirements. The fixed requirements consist of LMES courses required to maintain qualification in job fundamental and duty area access training. The flexible requirements include an individual Development Plan if appropriate, optional LMES and/or off-site training to enhance and diversify the individuals knowledge, skills, and abilities, and any training needed to address performance deficiencies. facility or procedure changes, or applicable operating expeniences.

Figure 1 - Qualification Paths

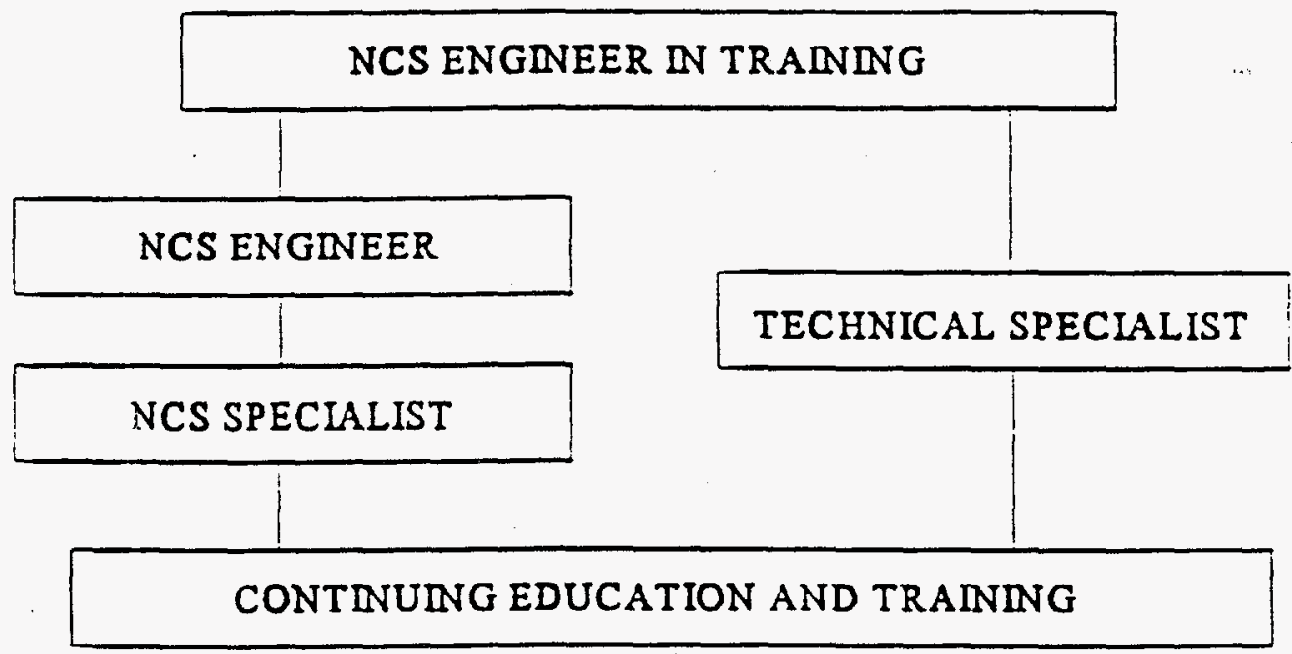


Y YDD-694, Rev. 3

9/6/96

Page 7 of 18

\section{TASK AND DUTY ASSIGNMENT QUALIFICATIONS}

6.1 The qualification to perform NCS tasks or serve in NCS and training related duty assignments is attained on a task or duty assignment specific basis. Tasks and duty assignments addressed are listed below.

\subsubsection{NCS Task and Duty Assignment activities:}
6.1.1.1
6.1 .1 .2
6.1 .1 .3
6.1 .1 .4
6.1 .1 .5
6.1 .1 .6
6.1.1.7
6.1 .1 .8
6.1.1.9
6.1 .1 .10
6.1 .1 .11
6.1 .1 .12
6.1 .1 .13
Task 1 - External Monitoring
Task 2 - NCS Evaluation and Documentation
Task 3 - Operating Procedure Approval
Task 4 - NCS Computation
Task 5 - NCS Computation Review
Task 6 - NCS Evaluation and Documentation Review
Task 7 - Emergency Response Planning
Task 8 - Criticality Accident Alarm System Support
Task 9 - Order Compliance and NCS Procedures
Task 10 - Independent Technicat Review Board (ITRB)
Task 11 - Final NCS Technical Documentation Approval
Task 12 - NCS Program Oversight
Task 13 - Emisgency Operations Center (EOC) Support

\subsubsection{Training-related Duty Assignments:}

\subsubsection{Qualification Verification Official \\ 6.1.2.2 Mentor \\ 6.1.2.3 Training Coordinator}

6.2 NCSD personnel shall be qualified to periorm specific tasks through completion of the task specific quatification requirements while working toward the overail program qualification. Note that some tasks are functional area or computer code specific. Qualification in these tasks appties to performing the task for a specific functional area or computer code only.

6.3 When used as a basis for qualification. personnel qualified to a higher technical qualification than specified are considered qualified for the position/board/assignment/activity. The hierarchy of technical qualification, from fower to higher, is:
NCS Engineer in Training NCS Engineer NCS Specialist
or NCS Engineer in Training Technical Specialist

6.4 Summary descriptions, knowledge, skills and abilities (KSAs) requirements, experience requirements, and qualification requirements for the various tasks and duty assignments are provided in Table 1. 
Y IDD-694, Rev. 3

9/6/96

Page 8 of 18

Table 1 - Task and Duty Assignment Qualification

\begin{tabular}{|c|c|c|c|}
\hline 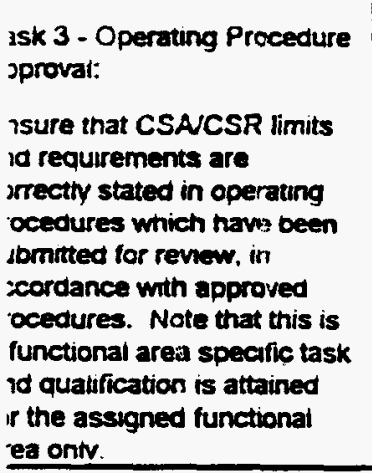 & $\begin{array}{l}\text { Knowledge of procedure } Y 10- \\
\text { 103. Writers Guide for } Y-12 \\
\text { Plant Operating Procedures. } \\
\text { Knowedge of operating } \\
\text { processes. equpment. and } \\
\text { support activities. Skill in } \\
\text { written communication. }\end{array}$ & $\begin{array}{l}\text { None beyond } \\
\text { NCS Engineer in } \\
\text { Training } \\
\text { requrements }\end{array}$ & $\begin{array}{l}\text { Qualified as NCS Engineer in Training and in Task } 1 \text { or } \\
2 \text {. Comptetion of the task requirements as tisted on the } \\
\text { assocuated Task } 3 \text { checksheet. This is an operating } \\
\text { facility spectic qualification. }\end{array}$ \\
\hline $\begin{array}{l}\text { ask } 4 \text { - NCS Computation: } \\
\text { efform NCS related } \\
\text { omputer catculations in } \\
\text { zcordance wh approved } \\
\text { rocedures. Note that this is } \\
\text { compurer code specific task } \\
\text { id qualification is attained } \\
\text { if the specified coders) only }\end{array}$ & $\begin{array}{l}\text { Knowledge of NCS theory. } \\
\text { ANS standards, LMES and Y- } \\
12 \text { Plant procedures, and } \\
\text { calculation methods. Skill in } \\
\text { the Use of approprate } \\
\text { computer hardware and } \\
\text { software. }\end{array}$ & $\begin{array}{l}\text { None beyond } \\
\text { NCS Engineer in } \\
\text { Training } \\
\text { requirements }\end{array}$ & $\begin{array}{l}\text { Qualification as NCS Engineer in Training and } \\
\text { comptetion of the task requirements as listed on the } \\
\text { Task } 4 \text { checksheet. including completion of a computer } \\
\text { code course taught or sponsored by recognized code } \\
\text { developers and/or maintainers or equivalent code } \\
\text { expentence. This is a computer code spectic } \\
\text { qualification. }\end{array}$ \\
\hline
\end{tabular}


Y/DO-694, Rev. 3

9/6/96

Page 9 of 18

\begin{tabular}{|c|c|c|c|}
\hline $\begin{array}{l}\text { ASK OR DUTY } \\
\text { SSIGNMENT }\end{array}$ & $\begin{array}{l}\text { APPLICABLE } \\
\text { KNOWLEDGE. SKIULS. } \\
\text { ABULTIES }\end{array}$ & $\begin{array}{l}\text { EXPERIENCE } \\
\text { REQUIREMENT }\end{array}$ & QUALIFICATION REQUIREMENT \\
\hline $\begin{array}{l}\text { ask } 5 \text { - NCS Computation } \\
\text { eview: } \\
\text { erform independent } \\
\text { ssessments of the adequacy } \\
\text { I NCS computations } \\
\text { rocuced by others in } \\
\text { ccordance with approved } \\
\text { rocedures. Note that this is } \\
\text { computer code specific task } \\
\text { nd quatification is attained } \\
\text { or the specified code(s) oniv. }\end{array}$ & Same as Task 4 & $\begin{array}{l}\text { None beyond } \\
\text { NCS Engineer in } \\
\text { Training } \\
\text { requirements }\end{array}$ & $\begin{array}{l}\text { Qualified as NCS Engineer in Training and in Task } 4 . \\
\text { Completion of the task requirements asted on the } \\
\text { aseoctated Task } 5 \text { checksheet. This ts a computer } \\
\text { code specific qualification. }\end{array}$ \\
\hline $\begin{array}{l}\text { ask } 6 \text { - NCS Evaluation ano } \\
\text { locumentation Review: } \\
\text { efform assessments of the } \\
\text { dequacy of CSAs or } \\
\text { :SRS/PDs and analyses } \\
\text { roduced by others in } \\
\text { ccordance with approved } \\
\text { rocedures }\end{array}$ & Same as Task 2. & $\begin{array}{l}\text { None bevond } \\
\text { NCS Engineer in } \\
\text { Training } \\
\text { requirements }\end{array}$ & $\begin{array}{l}\text { Qualified as NCS Engineer in Training and in Task } 2 . \\
\text { Completion of the task requiremems as isted on the } \\
\text { associated Task } 6 \text { checksneet. }\end{array}$ \\
\hline $\begin{array}{l}\text { Task } 7 \text { - Emergency } \\
\text { Response Planning: } \\
\text { Advise Plant Shin } \\
\text { Supenntendent and } \\
\text { Emergency Preparedness } \\
\text { ISS\&EP) in matters } \\
\text { oncerning Nuclear Criticality } \\
\text { ccident emergency } \\
\text { reparedness planning, in } \\
\text { ccordance with approved } \\
\text { rocedures. }\end{array}$ & $\begin{array}{l}\text { Knowledge of Y40 serves } \\
\text { procedures; plant facilties. } \\
\text { processes and equipment: } \\
\text { and roles and responsubilities } \\
\text { of organizations. Technical } \\
\text { knowledge of nuclear criticality } \\
\text { accident history and } \\
\text { expenence. }\end{array}$ & $\begin{array}{l}\text { None beyond } \\
\text { NCS Engineer in } \\
\text { Training } \\
\text { requirements }\end{array}$ & $\begin{array}{l}\text { Qualified as NCS Engineer in Training. Completion of } \\
\text { the task requirements as listed on the NCS Task } \\
\text { Checklist and associated Task } 7 \text { checisaneet inciuding } \\
\text { LMES Assembly Station Director training. }\end{array}$ \\
\hline $\begin{array}{l}\text { ask } 8 \text { - Criticality Acrident } \\
\text { larm System (CAAS) } \\
\text { upport: } \\
\text { articipate as NCSD } \\
\text { 3presentative on the } \\
\text { :onfiguration Control Board } \\
\text { or the CAAS and act as } \\
\text { ubject matter expert in } \\
\text { etting standards for the } \\
\text { iting and testing of CAAS } \\
\text { omponents. }\end{array}$ & $\begin{array}{l}\text { Knowledge of ANSI/ANS-8.3. } \\
\text { YO-151 and facility OSRs. } \\
\text { Knowledge of Y- } 12 \text { CAAS } \\
\text { deaign and installation. } \\
\text { Knowledge of Plamt Shift } \\
\text { Supenntendent and } \\
\text { Emergency Preparedness } \\
\text { (PSS\&EP) and Facility } \\
\text { Management Organization } \\
\text { (FMO) procedures for fixed } \\
\text { and portable alarms. }\end{array}$ & $\begin{array}{l}\text { None beyona } \\
\text { NCS Engineer in } \\
\text { Training } \\
\text { requirements }\end{array}$ & $\begin{array}{l}\text { Qualified as NCS Engineer in Training. Completion of } \\
\text { the task requirements as listed on the assoctated Task } \\
8 \text { checkstheet. }\end{array}$ \\
\hline $\begin{array}{l}\text { ask } 9 \text { - Order Compliance } \\
\text { nd NCS Procedures: } \\
\text { :valuate DOE orders and } \\
\text { uidelines: national } \\
\text { tandards: and LMES and } \\
\text { lant procedures for impact } \\
n \text { operations of the NCS } \\
\text { lepartment. }\end{array}$ & $\begin{array}{l}\text { Knowiedge of DOE orders } \\
\text { and guidelines. ANSI/ANS } \\
\text { standards. and LMES } / 12 \\
\text { procedures that govern NCS } \\
\text { activities. Skill in } \\
\text { interpretation of complex } \\
\text { technical documentation. } \\
\text { Skill in written and orat } \\
\text { communications, and in } \\
\text { interpersonal reiations. }\end{array}$ & $\begin{array}{l}\text { None beyond } \\
\text { NCS Engineer in } \\
\text { Training } \\
\text { requirements }\end{array}$ & $\begin{array}{l}\text { Qualified as NCS Engineer in Training. Completion of } \\
\text { the task requirements as IIsted on the assoctated Task } \\
9 \text { checksheet. }\end{array}$ \\
\hline
\end{tabular}


YOD-694, Rev. 3

9/6/96

Page 10 of 18

\begin{tabular}{|c|c|c|c|}
\hline $\begin{array}{l}\text { SK OR DUTY } \\
\text { SIGNMENT }\end{array}$ & $\begin{array}{l}\text { APPUCABLE } \\
\text { KNOWIEDGE, SKIULS. } \\
\text { ABUIUTES }\end{array}$ & $\begin{array}{l}\text { EXPERIENCE } \\
\text { REQUIREMENT }\end{array}$ & QUALIFICATION REQUIREMENT \\
\hline $\begin{array}{l}\text { sk } 10 \text { - Indepandent } \\
\text { zhnical Review Board } \\
\text { RB): } \\
\text { a Independent Technical } \\
\text { view Board prondes the } \\
\text { ependent revow of nuciear } \\
\text { icality evaluations and } \\
\text { noutations. }\end{array}$ & $\begin{array}{l}\text { Board members have a } \\
\text { thorougn knowiedge of NCS } \\
\text { theory and practice. applicable } \\
\text { orders, procedures and } \\
\text { documents, and plant } \\
\text { systems and processes. }\end{array}$ & $\begin{array}{l}8 \text { years nuclear } \\
\text { with } 5 \text { years } \\
\text { nuclear criticatity } \\
\text { safedy and } 3 \\
\text { years } y-12 \\
\text { nuclear criticality } \\
\text { safely }\end{array}$ & $\begin{array}{l}\text { Qualified as NCS Engineer or Technicat Specialiat and in } \\
\text { Task } 5 \text { andtor } 6 \text {. Completion of the teak requirements as } \\
\text { listed on the associated Task } 10 \text { checterect. }\end{array}$ \\
\hline $\begin{array}{l}\text { sk } 11 \text { - Final NCS } \\
\text { chnical Documentation } \\
\text { proval: } \\
\text { svide final approval of NCS } \\
\text { thnical documentation } \\
\text { cuments based on } \\
\text { :ommendation of the !TRB }\end{array}$ & $\begin{array}{l}\text { This is the NCSO } \\
\text { SUpenmendent's or his } \\
\text { designated alternate's } \\
\text { responsibitity }\end{array}$ & $\begin{array}{l}\text { None beyona } \\
\text { NCS } \\
\text { Supenntendent } \\
\text { or Task } 10 \text { as } \\
\text { appropriate }\end{array}$ & $\begin{array}{l}\text { Qualified as NCS Supenntendert or NCS Speciatiat and } \\
\text { in Task 10. Appointed in writing by the NCSD } \\
\text { Supenntendent. }\end{array}$ \\
\hline $\begin{array}{l}\text { sk } 12 \text { - NCS Program } \\
\text { ersight: } \\
\text { Recommend modifications of } \\
\text { NCS programs and } \\
\text { rocedures to ensure safety } \\
\text { of operations, and continued } \\
\text { mprovernem in the qualty } \\
\text { ind professionalism of the } \\
\text { vCS department. }\end{array}$ & $\begin{array}{l}\text { Individuals performing this } \\
\text { oversight need a thorougn } \\
\text { knowiedge of applicable NCS } \\
\text { documents and a knowledge } \\
\text { of the interaction of NCSD } \\
\text { with other disciplines. They } \\
\text { need skills in written and oral } \\
\text { communication, and in } \\
\text { interpersonat relations along } \\
\text { with the ability to anatyze } \\
\text { complex organizational } \\
\text { problems and synthesize } \\
\text { acceptable alternative } \\
\text { solutions. }\end{array}$ & $\begin{array}{l}\text { None beyona } \\
\text { NCS } \\
\text { Supenntendent. } \\
\text { NCS Specratist. } \\
\text { NCS Engineer, } \\
\text { Technical } \\
\text { Specialist. or } \\
\text { Group Leader as } \\
\text { appropnate }\end{array}$ & $\begin{array}{l}\text { Serving as NCSD Supenntendent or a NCSD Group } \\
\text { Leader. or quaufied as a NCS Engineer, NCS } \\
\text { Spectailist. or Technical Speclatist. Appounted in writing } \\
\text { by the NCSD Supenintendent. }\end{array}$ \\
\hline $\begin{array}{l}\text { ISK } 13 \text { - Emergency } \\
\text { Jerations Center (EOC) } \\
\text { Ipport: } \\
\text { tvise plant management of } \\
\text { IS considerations dunng } \\
\text { al or simulated } \\
\text { nergencies in accordance } \\
\text { th approved procedures. }\end{array}$ & $\begin{array}{l}\text { Personnet assigned this } \\
\text { responsibulity need a thorougn } \\
\text { technical knowedge of } \\
\text { criticality safety, plus } \\
\text { knowledge of the working } \\
\text { procedures of the EOC and } \\
\text { the ernergency response and } \\
\text { management plans of the } Y \text { - } \\
12 \text { plant. They need skill in } \\
\text { assessing and responding to } \\
\text { rapidly changing scenanos } \\
\text { and the ability to communicate } \\
\text { comptex issues clearly and } \\
\text { accuratety. }\end{array}$ & $\begin{array}{l}\text { None bevond } \\
\text { NCS Speclalıst }\end{array}$ & $\begin{array}{l}\text { Qualified as NCS Spectailst and in Task } 7 \text {. Comptetion } \\
\text { of the task requirements as IIsted on the associated } \\
\text { Task } 13 \text { checksheet. }\end{array}$ \\
\hline
\end{tabular}


YIDD-694, Rev. 3

9/6/96

Page 11 of 18

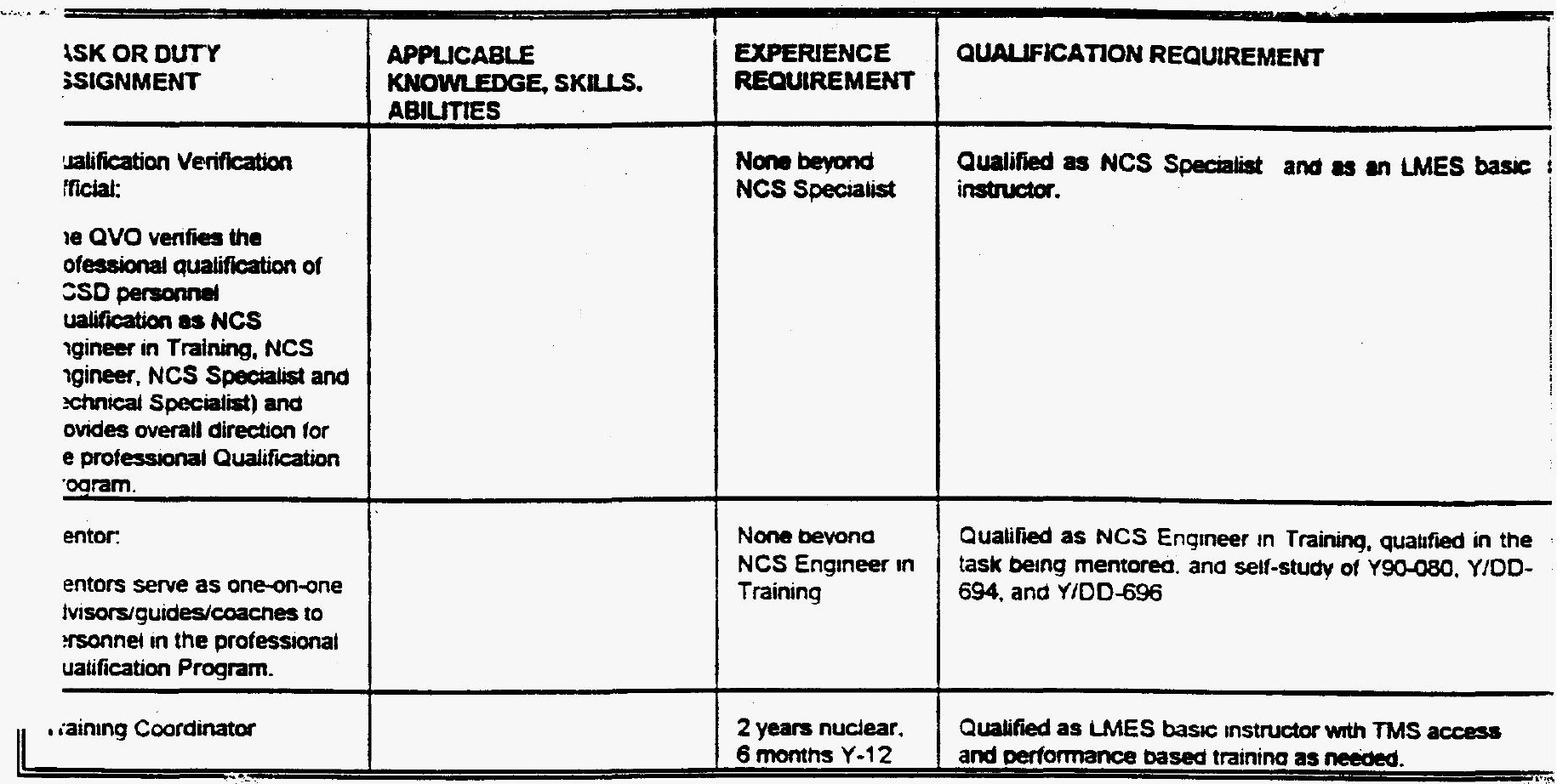

\subsection{PROGRAM, TASK AND DUTY ASSIGNMENT INITIAL QUALIFICATION}

7.1 All technical and managerial NCSD personnel. including temporary personnel who will perform NCS Tasks, shall be enrolled in a qualification program assigned by their supenisor. Multiple programs, for example, both a managerial and a technical program, may be assigned. Personnel who have completed any managerial or technical program shall be enrolled in continuing training. Additional requirements for subcontractor qualification are provided in Y90-110 and shall be followed.

7.2 The overall responsibility for an individual's training rests with the supervisor (Group Leader or Department Superintendent as appropriate). The Supervisor is assisted by the QVO. Training Coordinator (TC), and mentors. In general terms, the Supervisor assigns individuals to a qualification program consistent with their assigned and anticipated duties and the program is then executed through LMES courses and mentored training. The TC assists the Supervisor by notifying the Supervisor of LMES qualification maintenance courses that will be due, by interfacing with the LMES Center for Continuing Education (CCE) to sign the Candidate up for any required courses, and maintaining training records. The QVO assists mentors and verifies qualification at the completion of required training.

7.3 Training is guided by a program checklist and amplifying checksheets which are held by the Training Coordinator or Candidate until completion. Upon completion of training required for a task or program, the Supervisor recommends qualification.

7.4 After recommendation for qualification in a program, the TC forwards the completed mentoring checklist to the LMES Training Records Center (TRC) and requests generation of the Qualification Card. The TRC verifies that documentation supporting the completion of quatification requirements is on file and forwards the Qualification Card to the QVO for 
Y/DD-694, Rev. 3

9/6/96

Page 12 of 18

completion. Final quatification approval sha: is intermed by the NCSD Suberintendent. The completed Qualification Card is returned to the TRC and the TC issues a revision to Y/OD-587, "List of Qualified Personnel", to complete the process.

7.5 While in a Qualification Program above the Engineer in Training level, candidates attain qualification to perform task activities. Task qualification is documented on the Task Qualification Record, which is retained in the department training files. As with program qualification. after approval of the task qualification by the NCSD Superintendent the TC issues a revision to YIDD-587. "List of Qualified Personnel", to complete the process. For both program and task qualification, completed mentoring checksheets which support the mentoring checklists are retained in the department training files.

7.6. Tasks 4 and 5 are computer code specific and Tasks 1 and 3 are functional area specific. Initial qualification on these tasks may be attained with as few as one code or area, and over time qualification in additional codes or areas may be achieved. When adding a code or area to an existing task qualification. it is not necessary to requalify on the complete task. nor is a new Task Qualification Record required.

7.6.1 To add a new computer code to a Task 4 or 5 qualification, only the applicable Addendum Sheet provided with the Checksheet need be completed. Following completion, the TC issues a revision to Y/DD-587, "List of Qualified Personnel", to complete the process.

7.6.2 To add a new area to a Task 1 or 3 qualification, only the applicable portion of the Basic Faciity Knowledge Checksheet need be completed. Following completion, the TC Issues a revision to YIDD-587. "List of Qualified Personnel", to complete the process.

7.7 Each NCSD technical Candidate may have a lead mentor assigned by the QVO. If assigned, the lead mentor provides overall technical guidance to the Candidate during the qualification process and signs off completed tasks as required. Note that the lead mentor is not necessaniy the only mentor the Candidate will have. Other mentors may assist the lead mentor for individual checkist or checksheet items and sign off completed training. If no lead mentor is assigned. the Supervisor will provide overall technical guidance to the Candidate during the qualification process.

7.8 Oral boards shall be heid for qualification for all technical program qualifications except NCS Engineer in Training and for the NCS Computation and Evaluation Review tasks (Tasks 5 and 6).

7.8.1 When required, the oral board shall consist of, as a minimum:

7.8.1.1 For programs, the QVO. the NCSD Superintendent or Deputy Superintendent, and at least one NCSD member who is qualified in the subject program and not from the Candidate's group.

7.8.1.2 For tasks, the QVO, the applicable Group Leader. and at least one NCSO member who is qualified in the subject task and not from the Candidate's group. 
YIDD-694, Rev. 3

9/6/96

Page 13 of 18

7.8.2 Questioning by board members may proceed in any order, and shall continue until all board members are satisfied that the material has been covered in sufficient breadth to allow a judgment on the Candidate's knowiedge. Records shall be kept of the questions asked and the board's assessment of the Candidate's response on a scale of 1 - 10 on the Oral Qualification Board Record. The overall grade shall also be recorded on a basis of passffail. A "pass" resuit shall be a unanimous decision of the board. Weak areas noted during a passed oral board shall be discussed with the QVO prior to qualification.

7.8.3 If a Candidate fails the oral board, a study plan shall be developed by the QVO addressing the weak areas. After compietion of the study plan, and based upon the Candidate's Supervisor recommendation, a second oral board shall be held. The second oral board may focus on the Candidate's weak areas only, at the board's discretion.

7.8.4 Should a Candidate fail the second oral board. an individually designed plan shall be developed by the individual's Supervisor and QVO and approved by the NCSD Superintendent. This pian shall be composed of all or parts of the program for initial qualification. As a minimum, the content shall address aspects of qualification judged to be deficient.

7.9 For managerial posidions or non-technical duty assignments only, individuais may be assigned and serve in these positions prior to the completion of the associated Quatification Program or training as long as they are in the process of completing the training. Any interim measures judged necessary by the individual's Supervisor shall be approved by the individual's Supervisor and NCSD Superintendent or HSEA Manager as appropriate.

7.10 Experienced personnel, who may be either permanent staff, sub-contractors, or LMES employees on loan to NCSD, may have experience and qualifications from prior employment in the nuclear industry. In such cases, the qualification process may be expedited to credit previous knowledge, skills and abilities of the individual.

7.10.1 For experienced personnel, an Expenenced Personnel Evaluation board may be convened to evaluate the existing knowledge, skills and abilities of the individual and define which portions of the assigned NCS training need to be completed. The board shall consist of a QVO and at least one other NCS Specialist or NCS Engineer.

7.10.2 Actions of the qualification board shall be documented by completing the Experienced Personnel Evaluation Form and by indicating which requirements on the Mentoring Checklists and Checksheets are excepted inctuding the basis of the exception. Completed Experienced Personnel Evaluation forms shall be retained in the NCSD training records and documented in the LMES records with a request for exception if necessary. Acceptable bases for exception of a qualification requirement are provided in Y90-020. In addition, for personnel in managerial positions only, an item may be excepted or waived if it will have no bearing on the duties which will be performed after qualification. 
Y/DD-694, Rev. 3

9/6/96

Page 14 of 18

7.10.3 Acceptable documentation of past performance may be any of the followng, in order of preference:

7.10.3.1 A copy of the output (for example, the report, calculation, or attendance certificate).

7.10.3.2 A signed copy of the Candidate's resume, if the activity is documented in the resume.

7.10.3.3 A signed statement from the Candidate attesting to performance of the activity.

7.11 The process steps leading to qualification as a NCS Engineer in Training are listed below.

7.11.1 Enter Candidate in NCS Engineer in Training qualification program (TMS \# 5939)

7.11.1.1 Supervisor obtains associated Mentoring Checksheets from the TC for Candidate.

7.11.1.2 If desired. QVO assigns a lead mentor.

7.11.1.3 TC verifies education and experience is documented in the training records, signs-up Candidate for LMES courses, and notifies Supervisor of schedule.

7.11.2 Complete NCS Engineer in Training qualification

7.11.2.1 Candidate performs self-study activities.

7.11.2.2 Candidate discusses with mentor completion of self-study tasks.

7.11.2.3 Candidate attends LMES courses.

7.11.3 NCS Engineer in Training qualification verification

7.11.3.1 Supervisor reviews checklist and checksheets for completeness and recommends to QVO that Candidate be quatified.

7.11.3.2 QVO reviews and verifies Candidate's technical qualification.

7.11.3.3 TC forwards completed checklist to Training Records Center and requests generation of Quatification Card.

7.11.3.4 All complete the Qualification Card, NCSD Superintendent approves qualification.

7.11.3.5 TC enters qualification as NCS Engineer in Training in Candidate's training record and revises Y/OD-587.

7.12 The process steps leading to qualification as a NCS Engineer, NCS Specialist. or Technical Specialist are listed below.

7.12.1 Enter Candidate into individualized continuing training program (TMS \# 5770).

7.12.1.1

On at least an annual basis. TC issue to Supervisor a listing of continuing LMES courses needed.

7.12.1.2 On an annual basis. Supervisor and Candidate jointly develop continuing training activities beyond the LMES requalification activities for the year.

7.12.1.3 As required. TC signs-up Candidate for LMES courses and notifies Supervisor of schedule and Candidate attends courses. 
Y/DD-694, Rev. 3

9/6/96

Page 15 of 18

7.12.2 Enter Candidate in NCS Engineer. NCS Specialist or Technical Specialist quatification program, as appropriate (TMS \# 5761, 5562 or 5764)

7.12.2.1 Supervisor obtains associated Mentoring Checksheets from the TC for Candidate.

7.12.2.2 . If desired, QVO assigns lead mentor.

7.12.3 While in training, qualify to perform specific tasks

7.12.3.1 Candidate performs task activities.

7.12.3.2 Mentor signs off task accomplishment.

7.12.3.3 Supervisor recommends and QVO reviews and verifies Candidate's qualification and convenes an oral board (Tasks 5 and 6 oniy).

7.12.3.4 All complete Task Qualification Report. NCSD Superintendent approves qualification, and TC enters qualification for the task in Candidate's training record and revises Y/DD-587.

7.12.4 Complete NCS Engineer. NCS Specialist. or Technical Specialist qualification

Candidate performs task activities and attends required LMES courses.

7.12.4.2 Mentor signs off task accomplishment.

7.12.4.3 TC notifies Supervisor of LMES training due and signs the Candidate up for courses as required.

7.12.5 NCS Engineer. NCS Specialist, or Technical Specialist qualification verification

7.12.5.1 Supervisor reviews checklist and checksheets for completeness and recommends to QVO that Candidate be qualified.

7.12.5.2 QVO reviews and verifies Candidate's technical qualification and convenes an oral board.

7.12.5.3 TC forwards compieted checklist to Training Records Center and requests generation of Qualification Card.

7.12.5.4 All complete the Quatification Card, NCSD Superintendent approves qualification.

7.12.5.5 TC enters qualification as NCS Engineer. NCS Specialist or Technical Specialist as appropriate in Candidate's training record and revises Y/DD-587.

7.13 The process steps leading to qualification as a NCS Superintendent are listed below.

7.13.1 Enter Candidate in NCS Superintendent qualification program (TMS \# 5763)

7.13.1.1

Candidate and HSEA Manager develop IDP.

7.13 .1 .2

$T C$ verifies education and experience is documented in the training records. signs-up Candidate for LMES courses and notifies Candidate of schedule. 
Y/DD-694, Rev. 3

$9 / 6 / 96$

Page 16 of 18

7.13.2 Complete NCS Supeininierident qualification

7.13.2.1 Candidate completes IDP.

7.13.2.2 Candidate discuss with HSEA Manager completion of administrative self-study tasks as appropriate.

7.13.2.3 Candidate discuss with QVO completion of technical self-study tasks as appropriate.

7.13.2.4 Candidate attends LMES courses.

\subsubsection{NCS Superintendent qualification verification}

7.13.3.1 HSEA Manager reviews IDP for completeness and recommends that Candidate be qualified.

7.13.3.2 TC forwards completed IDP to Training Records Center and requests generation of Qualification Card.

7.13.3.3 All complete the Qualification Card.

7.13.3.4 TC enters qualification as NCS Supenntendent in Candidate's training record and revises Y/DD-587.

\section{MAINTENANCE OF QUALIFICATION AND REQUALIFICATION}

8.1 For NCSD technical perscrnel, maintenance of qualification shall be part of continuing education ard training. LMES required courses are part of the fixed portion of that program. Maintenance of technical task and program qualifications shatl be part of the flexible portion of the program and is achieved by:

8.1.1 Satisfactory performance as documented during annual performance reviews. An overall performance rating of "CM" or higher shall be considered satisfactory. Supervisors shall provide the QVO a listing of any group personnel who fail to meet the criteria on an annual basis in conjunction with the Performance Planning and Review process along with a recommendation on which tasks or programs requalification should be conducted.

8.1.2 Compietion of NCSD Continuing Technical Training. Continuing Technical Training shall be a combination of required reading and NCSD technical discussion meetings. The Continuing Technical Training program is discussed in Y/DD-710 and addresses:

8.1.2.1 Changes in LMES, $Y-12$ and NCSD procedures

8.1.2.2 Changes in DOE Orders and Industry Codes and Standards

8.1.2.3 Industry and site experience, including lessons learned

8.1.2.4 Client feedback

8.1.2.5 Deficiency trends

8.1.2.6 Management seif-assessments

8.1.2.7 Internal and external audits and surveiliance 
YDD-694, Rev. 3

9/6/96

Page 17 of 18

8.2 An individual's qualification in a program or task may be removed tor failure to meet the requirements of section 8.1 or for reasons of unsatisfactory performance. As necessary, the individual's Supervisor shall recommend removal of qualification to the QVO. The QVO shall develop and recommend corrective action to the NCSO Superintendent who shall approve any removal of qualification. Should qualification in a task or program be removed for any reason, the TC will remove the individual from the list of qualified personnel, Y/DD-587.

8.2.1 Removal of task or program qualification for reasons of unsatisfactory performance shall be based on continuing failure to perform the activities embodied by the qualification in a satisfactory manner and documented in the Performance Planning and Review process and/or in the Positive Discipline program as appropriate.

8.2.2 Requatification following removal for reasons of unsatisfactory performance shall be performed by completion of an individuatly designed program developed by the individual's Supervisor and QVO and approved by the NCSD Superintendent. This program shall be composed of all or parts of the program for initial quatification. As a minimum, the content shall address aspects of qualification judged to be deficient based upon the unsatisfactory performance which led to the removal of the qualification.

8.3 Failure to complete LMES required Job Fundamental or Duty Area Access compliance courses or NCSD Continuing Technical Training shall be rectified at the earliest opportunity, but formal removal and requalification on NCSD technical program or task qualifications is nc: required. Supervisors may recommend disqualification should the deficiency in LMES required Job fundamental or duty area access compliance courses or NCSD Continuing Technical Training impact the ability of the deficient individual to perform assigned tasks.

8.4 On a biennial basis. satisfactory completion of the continuing training shall be documented by the Training Coordinator (TMS Module 17890, NCS Engineer Requalification).

QUALIFICATION TRACKING

9.1 The completion of a Qualification Program shall be documented in the LMES TMS system with a quatification card as specified in Y90-010, a copy of which shall be maintained in the department level training records.

9.2 The completion of task qualification requirements shatl be documented with a Task Qualification Record which shall be maintained in the department level training records.

9.3 Y YOD-587, List of Qualified Personnel, shall be maintained by the NCSD Training Coordinator and contain a listing of NCSD personnel who are currently quatified in programs, tasks, and duty assignments and the date their qualification was attained. An example of the tables which make up Y/DD-587 can be found in Y/DD-696. The list shall be revised as necessary to account for new, removed, and restored qualifications.

9.4 On a quarterty basis, the Training Coordinator shall generate a Requirements/Qualification Status Report for all NCSD personnel and distribute the list to the applicable supervisor. 
Y IOD-694, Rev. 3

9/6/96

Page 18 of 18

\section{EVALUATION OF QUALIFICATION AND TRAINING}

10.1 Periodic self-assessments of the qualification program and associated training shall be performed to evaluate the effectiveness of the program. The assessments shail be performed on an annual basis and are intended to address three subjects as a minimum. Questions listed below are examples oniy.

10.1.1 Compliance: is the program documentation complete and correct? Are technical and managerial personnel enrolled in the quatification program? is the program current with respect to applicable DOE Orders, industry standards and experience, and LMES $Y-12$ procedures?

10.1.2 Implementation: Are personnel completing qualification within the anticipated intervals? Is off-site training being utilized? Are personnel completing their assigned continuing development? Are managers and Group Leaders completing their Individual Development Plans as applicable?

10.1.3 Effectiveness: Is the program producing sufficient qualified staff? Does the training program provide the knowledge required? Is it being retained after qualification?

10.2 The annual self-assessment shall be directed by the QVO and conducted in accordance with YDD-552, Nuctear Criticality Safety Department Self-Assessment Program, DOE Standard 1070-94, and Y90-100, Conduct of Training Program Evoluation, as appropriate.

10.3 A biennial review of training materials shall be conducted in accordance with Y90-100.

10.4 The results of all reviews and seif-assessments, inciuding resuiting corrective actions, shatl be filed in the department training files. 
Distribution:

K. J. Carroll

S. O. Oran

R. G. Taylor

C. A. Worley

A. K. Lee/DOE-OSTI, 9983-30, MS-8175 (2)

Y-12 Central Files, 9711-5, MS-8169 